\title{
EXPLORING APOLOGY STRATEGY BY INDONESIAN PUBLIC FIGURES: A PRAGMATIC STUDY IN SOCIAL MEDIA
}

\author{
Budi Abudin'1, Hanna Sundari² \\ Fakultas Pascasarjana, Universitas Indraprasta PGRI Jakarta \\ I'budiabudin@gmail.com, ${ }^{2}$ hanna.sundari@gmail.com
}

\begin{abstract}
Abstrak
Tokoh publik cenderung menggunakan media sosial untuk meminta maaf kepada masyarakat karena sosial media memiliki kepraktisan dan efektifitas. Meskipun permintaan maaf merupakan fenomena sosial yang telah banyak diteliti di negara-negara berbahasa Inggris, permintaan maaf secara publik di Indonesia masih kurang mendapat perhatian para ahli bahasa. Tulisan ini membahas tindak tutur permintaan maaf dari tokoh public dari Indonesia pada tahun 2020 dengan menganalisis tiga video dari YouTube. Kemudian, data dianalisis dan dikategorikan sesuai dengan kerangka Murphy (2014). Temuan penelitian mendapati bahwa tokoh publik Indonesia mengungkapkan permintaan maaf melalui tiga kategori: eksplisit, konvensional tidak langsung, dan non-konvensional tidak langsung. Lebih lanjut, memberikan penjelasan, cerita, atau alasan menjadi strategi permintaan maaf yang paling banyak digunakan. Selain juga, pernyataan tidak ada niat dan ungkapan perbaikan.
\end{abstract}

Keywords: Pragmatik, Permintaan Maaf, Indonesia, Youtube, Tokoh Publik

\begin{abstract}
Public figures tend to use social media platforms to apologize in public due to its practicality and effectiveness. Although public apology as a social phenomenon has been extensively studied in the English-speaking world, Indonesian public apologies have less attention from linguists and management scientists. This paper examines the speech act of apologizing made by Indonesian Public Figures in 2020 by analyzing three videos collected from YouTube. The data of the study was analyzed based on Murphy's framework of formulate (2015). Findings include that Indonesian public figures prefer all three categories of apology strategy: explicit, conventionalindirect, and non-conventional-indirect strategies. Mover, explanation, account, or excuse become the most frequent used to express their apology. It was then followed by expression of lack of intent and statement of repair.
\end{abstract}

Keywords: Pragmatic, Apology, Indonesia, Youtube, Public Figures

\section{INTRODUCTION}

An apology is not only express regret, but also contributes to interpersonal relationship management and image repair. A sincere apology can ease rather than make heavier the situation, reassure victims and netizens, and keep social harmony and stability. Public apology phenomenon is principally suitable for linguistic analysis as it provides 'media texts or practices where the language is itself implicitly or explicitly thematized (Johnson and Ensslin, 2007:6). Today, public figures tend to use social 
media as platforms to apologize to audiences, particularly when the occurrence of offense originated from social media (Ulmer, Sellnow, \& Seeger, 2013). Thus, confronted with crises or scandals that arouse controversies, public figures tend to make apologies on social media like YouTube instead of traditional media to eliminate harmful influences. Launched in 2005, YouTube, an American online video-enabled social media platform, has become one of the most influential online platforms for people to exchange information. YouTube as a timely and effective channel of video sharing now has billions of users worldwide paying attention to the interaction with their followers to publicize themselves and shape positive images.

Different perspectives and different findings of apologies have been investigated by linguists and management experts. Most of the linguistic studies on apology focus on the composition of apologies by categorizing their pragmatic strategies (Olshtain \& Cohen, 1983; Holmes, 1990; Trosborg, 1995). Empirical research also conducted to analyze apology, as a speech act, in different cultures and languages, attempting to figure out some universal patterns (Shahrokhi \& Jan, 2012; Kadar, Ning, \& Ran, 2018). In the management field, scholars provide magnificent impact to the effects and strategies of apologies as an image repair device (Kampf, 2009). Benoit proposed five broad categories of image repair strategies and analyzed some apologies made by corporations, politicians, and celebrities in traditional media (Benoit, 1997). Based on his theory, scholars also analyzed apologies posted on Twitter and YouTube (Page, 2014; Sandlin, and Gracyalny, 2018).

The beginning of apology investigation was done in the early 80s. Owen (1983) considered apologies from a Goffmanian view, as a type of tradition action, especially a type of refinement interchange. In recent years, study of apology has become an important and engaging topic in linguistics, specifically in pragmatics field. Many scholars have discussed the apology from some perspective, such as; concept of face politeness principle, and speech act theory (Searle, 1979; Leech, 1983; Goffman, 1959). Brown and Levinson (1987) indicate that an apology can be categorized as a face threatening act. After the speaker damages the hearer's face wants to be freed in one's actions, s/he should apologize, which also damages the apologizer's desire to be accepted.

Many researchers have investigated pragmatic strategies in employing apologies, and many have conducted various empirical research and forms of surveys to prove their theories. Scholars emerged a basic set of strategies (also known as semantic formulate) used, singly or in combination, to analyze an apology. Olshtain \& Cohen (1983) proposed when the offending participant agrees to apologize, the five potential semantic formulae may be employed; first, expression of apology, second, explanation or account of the situation; third; acknowledgment of responsibility, fourth; offer of repair, and the last is promise of forbearance.

These semantic formulate have been used as a basic set of strategies to study interpersonal apologies across different speakers, cultures, and languages (see Cohen \& Olshtain, 1981, in Olshtain \& Cohen, 1983). Arguably, one of the most impactful of these studies has been Blum-Kulka and Olshtain's Cross-Cultural Study of Speech Act Realization Patterns (CCSARP) on requests and apologies, which has influenced virtually all following studies on apology. Blum-Kulka and Olshtain in the CCSARP, notice that "the most direct realization of an apology is done via an explicit illocutionary force indicating device" but apologies can "be realized by reference to a set of specified propositions", instead of or in addition to using an IFID (1984). 
The categorizations are very engaging yet comprehensive. Just as Page (2014) using the framework to his research of corporate/customer apology interactions on Twitter; and Hargie, Stapleton, \& Tourish (2010) analyzing the apologies of bank CEO's in the UK House of Commons after the 2008 Banking Crisis; and Murphy (2014, 2015) examining political apologies of British MPs, again in the UK House of Commons. Each of these researches has built on the semantic of formulae, with Murphy (2015).

Furthermore, there are very few studies that investigate the strategies occurred in Indonesian apologies, propose specific patterns. Research on apology based on the Indonesian language is far from enough compared with that in English and some other languages. Wouk suggests that in order to fully investigate cross-cultural differences in the language of apology, it will be necessary to carry out additional studies, with both more carefully controlled and more naturalistic data of Indonesian apologies (Wouk, 2006). Since she used 'Discourse Completion Task' (DCT) in her study of Lombok Indonesian apology, it became less natural but still shed light to the study of Indonesian apology. This study is conducted to enhance the pragmatic study of Indonesian apologies. Therefore, it is of great significance to investigate Indonesian public figures apologies posted on YouTube to examine the pragmatic strategies of apologies. The goal of this study is to explore apology strategies used by Indonesian public figures posted on YouTube. Accordingly, this study is to investigate whether the above categorization and formulas can be applied in Indonesian apology. More specifically, the present study attempts to find out what are the Indonesian public figures apologize on YouTube during crisis to alleviate bad influence and restore the positive image.

\section{RESEARCH METHOD}

This study focused on the textual analysis that is the clause-by-clause breakdown and analysis of each text at the level of linguistic features. The sample of the study were three video apologies from YouTube. The videos were including four public figures, especially in social media, such as YouTuber, influencer and/or beauty vlogger. They were GA, IK, U, and $\mathrm{K}$ whose YouTube channels reach million subscribers. Their videos and expressions were selected since they hit million views, but then they became controversial among Indonesian netizens at that time. In the current work, we used Murphy's framework of apology strategy $(2014,2015)$, as shown in Table 1.

Table 1 Apology Strategy (Murphy, 2015)

\begin{tabular}{|c|c|c|c|}
\hline Broad Category & & Sub & category (Individual Category) \\
\hline A. Explicit & Expression & A1 & A formative IFID \\
\hline Apology & & $\mathrm{A} 2$ & A Commissive with "apology" as direct object \\
\hline B. Conventional & (indirect) & B1 & An expression of Regret \\
\hline apology formula & & B2 & $\begin{array}{l}\text { A request for } \\
\text { apology/forgiveness }\end{array}$ \\
\hline & & B3 & A statement of Desire \\
\hline & & B4 & A Statement of Obligation \\
\hline C. Non-conventional & Indirect & $\mathrm{C} 1$ & Explanation, account, and excuse \\
\hline apology strategy & & $\mathrm{C} 2$ & Accepting the blame \\
\hline & & $\mathrm{C} 3$ & Expressing self-deficiency \\
\hline & & $\mathrm{C} 4$ & Recognizing of $\mathrm{H}$ as entitled to apology \\
\hline & & $\mathrm{C} 5$ & Expressing lack of intent \\
\hline
\end{tabular}


C6 An offer/statement of repair/redress

C7 A statement of non-recurrence/forbearance

Furthermore, the second researcher transcribed the utterances made by the figures on the videos. After the transcription was ready, the next was data analysis. The steps were divided into 3: analyzing each apology text, coding each text independently, and then comparing the texts within each apology type to discover strategy use patterns. The results of this analysis are presented in findings and discussion respectively. Finally, these texts were compared across apology types to examine what apology strategies are used in general.

\section{RESULT AND DISCUSSION}

After gathering and analyzing the data, we can see in general that the three figures in this study applied more than one strategy to express their apology to the public. Here are presented the strategy apology of each video, it is then followed by the summary of the apology strategy made by Indonesia public figures.

\section{Strategy Apology of Video 1 (GA)}

GA is an Indonesian actress who debuted her career in a direct-to-video series in 2006. She currently has nearly 3 million subscribers in August 2020. The case began when she invited one of the celebrities, IK, to her podcast. She asked about lifestyle during the pandemic to the guest star. Surprisingly the response given by the guest star was totally contradicted with government directives who suggested wearing masks and maintaining healthy by washing hands.

This had become a hot issue because when a pandemic like this the speakers seemed to be inviting the audience to heed the rules that have been set. Therefore, for various sources, GA as the host in her podcast shows apology for the YouTube content she uploaded in May 2020.

She started her apology by greeting 'Selamat sore' means good afternoon. Then she continued her words by introducing herself and mentioned her achievement and her most genuine aim of her content.

"Saya Gxxx Axxx sebagai content creator, saya telah menghasilkan ratusan video. selalu saya sampaikan bahwa tujuannya adalah mengedukasi dan menginspirasi."

(I'm Gxx Axx, as a content creator, I have made hundreds of videos. I always mention that the purpose is to educate and to inspire)

Specifically, she claimed herself as a content creator and her achievement to make sure that she is aware of her position as a public figure. Then, she explained the purpose of her video was for positive exposure. She used explanation followed by expression of lack intent strategy at the beginning of her speech.

"Dari ratusan konten timbullah satu konten yang dianggap banyak orang tidak bersimpati atau tidak menghargai apa yang terjadi saat ini. Dengan segala kerendahan hati saya memohon maaf kepada seluruh orang yang merasa tersinggung, marah ataupun bersedih atas konten yang saya upload. Saya mau minta maaf." 
(From those hundred contents, there was a content that assumed by most people wasn't sympathize or disrespect the current situation. Modestly, I apologize to all those who feel offended, angry or sad about the content that I uploaded. I want to apologize)

The previous explanation helped her emphasize that there was only a little content from her YouTube channel that discomfort the audiences then she felt sorry. She used explicit expression of apology, commissive apology with direct object followed by performative IFID.

"Saya sadar betul bahwa sekarang kita sedang bersama-sama memerangi covid-19. Tidak pernah sekalipun ada niatan saya untuk meremehkan atau menganggap enteng pandemi ini."

(I'm really aware that we are fighting covid-19 together. There is no intention to underestimate this pandemic)

She gave more explanation to strengthen the expression of apology by sharing collective thoughts that she was also being the part of the pandemic survivors; then it followed by expression of lack of intent.

"Saya telah mentake down video saya agar tidak berkepanjangan. Sekali lagi atas hati yang tersakiti, saya memohon maaf."

(I have taken down the video to prevent any further problems. Once again, for the hurt, I apologize)

As a statement of repair, she said that she had taken down the video in order to alleviate the condition and it followed by commissive apology with direct object.

"Semoga dengan kejadian ini, saya menjadi content creator yang lebih memberikan manfaat lagi dan menjadi manusia yang lebih baik lagi. Terima kasih."

(Hopefully, by this event, I'd be more useful content creator and became a better person. Thank you)

Finally, she closed her apology by giving the statement of non-recurrence or statement of forbearance. Thus, she preferred to give more explanation in her apology rather than other apology strategies.

\section{Strategy Apology of Video 2 (IK and U)}

She is a YouTuber known as a hilarious beauty vlogger and often produces interesting and unique content. As a beauty vlogger, she has many loyal fans. Her YouTube channel now has more than 2.6 million subscribers. IK is also famous as a celebrity. Her Instagram followers have reached one million. Not only actively uploading videos on YouTube and appearing on Instagram, but she also has other social media accounts, such as TikTok and Ask.fm.

In May 2020, she was invited to GA's YouTube channel to be a guest star. She was very talk-active and cheerful. In the middle of the podcast, she was asked about some daily activities during the pandemic. Surprisingly the answer was very contradictive with the government policy to follow health protocols including staying at home, practice $3 \mathrm{M}$, such as wearing a mask properly, wash hands with running water, and maintaining a safe distance (Ministry of Health of the Republic of Indonesia, 2020). 
Thus, many netizens and people felt discomfort with her statement which was not ignorantly applying those protocols. Few days later, she was invited to Deddy Corbuzier YouTube channel to clarify and announced her apology statement accompanied by her husband, U. Here are their statements:

"Pokoknya abis kejadian ini aku mau lebih banyak belajar. Aku mau minta maaf sama semuanya."

(After this event, I just want to learn more. I want to apologize to all of you)

She started her apology with statement of repair followed by direct expression of apology. Visually, she cried while spoken the statement, but we focused on the speech production. Probably it could emphasize to what she said and exposing more about the expression of regret.

"Aku ngga tau aku bakal terjadi kaya gini omongan aku bakal jadi gini aku tuh ga tau. Aku sama sekali bukan untuk meremehkan tenaga medis, engga." (I didn't know it would be like this, my speech, I didn't expect, I didn't know. I didn't mean to underestimate the medic)

Then, she continued with statement of lack of intent followed by recognition of hearer $(\mathrm{H})$ as entitled to apology. Specifically, she said to the medic because she thought that they were the front line that was facing the pandemic.

"Emang pure. bener kata kalian aku bodoh jadi di video itu aku bodoh aku ngomong ga dipikirin dulu itu bener banget. aku sama sekali nggak nolak kalian ngatain aku tuh engga karena aku tau disitu aku salah." (Purely, I was stupid as you said, so in that video I was stupid. I didn't weight my words. That was true.)

She accepted the blame from netizens for her statements. She expressed herself deficiency by saying 'aku bodoh' (I was stupid). She said that she would not deny the people's blame and she realized that she was mistaken.

"Pokoknya aku mau minta maaf dan kalian jangan dengerin omongan aku yang itu karena sebenernya aku pun pake masker dan aku tuh juga di tas aku tuh aku selalu bawa tisu basah yang ada alkohol alkoholnya gitu aku selalu bawa jadi omongan aku disitu bener bener ngawur banget."

(I just want to apologize, and you don't listen to what I said because the fact was, I wear mask, and in my bag, I always bring wet tissue containing alcohol. I always bring it, so my speech at that time was really messed up.)

She continued by expressing the direct expression of apology, followed by an explanation or excuse that she followed the rule by wearing masks and brought wet tissue everywhere. She claimed that it was just a slip tongue, and she felt sorry about it.

"Aku mau minta maaf bener-bener minta maaf sama kalian semua jangan ikutin omongan aku yang itu please kalian jaga kesehatan terus juga selalu pake masker dan selalu jaga kebersihan."

(I want to apologize. Truly apologize to all of you and don't follow my speech. Please keep your health and always wear mask and always keep clean.) 
She closed her apology by emphasizing the direct expression of apology. She really felt sorry and finally she used statement of offering. Thus, she preferred to use accepting the blame and offering/statement of repair/redress in her apology strategies.

Meanwhile, $\mathrm{U}$ was there as a husband of IK. He also made an apology to netizens.

"Kita tuh cuma kaya begitu ada PSBB disuruh dirumah ya kita kan sama sama tau kan ya YouTuber kerjanya di rumah."

(We did that only when there was lockdown (PSBB) stayed at home as we knew that YouTuber worked from home)

Firstly, he claimed himself as a YouTuber. He said that he followed the rules and he gave explanation about how a YouTuber worked.

"Semua konten gua itu gua setiap hari ngupload selama bulan ramadan dan dia juga, itu semuanya dirumah."

(I uploaded all of my contents every day during Ramadhan, she's too. It was made from home)

Then he gave more explanation to strengthen his previous statement.

"McD Sarinah aja yang itu emang gua juga ga ngerti kenapa gua kepikiran kaya gitu dan itu salah, jangan ditiru ya guys ya." (McD Sarinah was the only one, I didn't have a clue why I did it and it was wrong. Please guys don't do it.)

He told about a certain place because he also had an issue with the place. He went to the closing ceremony of McDonaldSarinah in the situation of the pandemic.

"Jadi dikesempatan kali ini juga gua Gxxx Sxx biasa dikenalnya Uxx juga mau minta maaf untuk masyarakat yang merasa diresahkan baik oleh istri gua atau pun juga gua gitu ya dengan sangat rendah hati gua minta maaf untuk semuanya." (So, in this opportunity. I'm Gxx Sxx, commonly known as Uxx, want to apologize to people who offended by my wife and me. I humbly want to apologize to all of you.)

Here he introduced himself and he used direct expression of apology strategy to strengthen his wife apology.

"Pokoknya apa yang dibilang sama Ixx yang itu salah jangan ditiru kalian harus tetep ini bener-bener kaya kalian tuh harus bener-bener stay healthy, stay clean dirumah gitu kan."

(No matter what Ixx said it was wrong, please don't do that. I mean it. You have to keep healthy and stay at home.)

He finished his apology using offering strategy just like his wife before. Mostly, he used explanation in his apology rather than other strategies.

\section{Strategy Apology of Video 3 (K)}

$\mathrm{K}$ is a YouTuber and Instagram celebrity from Indonesia. She is known after creating makeup tutorial content by using balloons to replace the beauty blender function. In July 2020, her YouTube channel has more than 1 million subscribers. K's makeup tutorial content, which she called "beauty vlogger", was first uploaded on April 
1, 2018. K admitted that she often experienced abuse because she had a stocky body and was not tall. However, $\mathrm{K}$ was determined to make a video to prove that even ordinary people can still be beautiful.

On May 29th, 2020, she released a music video with the title "Keke bukan Boneka". The video immediately hit the first rank on YouTube Indonesia. In July 2020, the video was watched more than 12 million times. However, on the same day, YouTube removed the video because of the copyright claim after the part of the lyrics was known to be similar to the song "Aku bukan boneka" by Rinni Wulandari composed by Novi Umar. Previously, K said she did not expect the song to be similar to the song "Aku bukan boneka".

She made an apology via Dunia Manji YouTube Channel to all stakeholders who objected to the presence of the song. On June 5, 2020, the video clip can be accessed again on YouTube and has been watched 42 million times. Here are the apology statements;

"Bukan, bukan masalah kaya gitu. Lah aku itu kan pas waktu menciptakan lagu itu kan mantan aku kan gini kan "kau bukan boneka" ini apa gitu loh kaya ngeledek gitu kan. Ngeledek kecil kecilan gitu kan." (No. Not like that. When I create the song, my ex said "You're not a doll" "What was that" I said. Just like a joke)

She started the apology with denial then she explained that she had experience about why she made the song. She used explanation strategy in her apology.

"Terus ya gimana kalau misalnya aku buat puisi atau kata kata gitu, terus habis tuh buat kata kata pas waktu di studio gitukan aku kan dulu kursus ukulele tuh kursus ukulele habis itu dibuatin aransemen dan ya buat lagu gitu loh jadi lagu gitu loh."

(Then, how if I write a poem or words and then in the studio, previously i took ukulele's course, then the arrangement was made then became a song)

She continued her story about the reason for the song. She used more explanation apology strategy in this part.

"Aku ngga tau kalau misalnya lagunya itu hampir mirip aku juga ngga tau gitu loh. Ko tiba tiba kaya gitu aku jujur aku ngga tau tapi kalau misalkan aku ada salahnya aku minta maaf kaya gitu aja. Aku minta maaf banget." (I didn't know if the song was similar. I didn't know. It's so sudden. Honestly, I didn't know but if I was wrong, I'm sorry. I'm so sorry.)

Then she used expression of lack of intention, and it followed by conventional indirect apology strategy using a statement of obligation.

"Aku bukan berniatan buruk atau kaya ambil lagu orang atau kaya gimana hak cipta orang aku ambil, bukan aku tuh cuma niat buat lagu dan bener bener ga tau kalau lagunya itu sama kaya gitu loh." (I had no bad intention or took someone's song or claimed the other's copyright. No. I just wanted to make a song and I had no clue if the song is similar.)

In the end, she used expressions of lack of intent to strengthen the statement. She preferred to use expression of lack of intent strategy followed by explanation, account, and excuse in her apology. 
From the three videos, they were expressed through social media either YouTube channel or Podcast. GA expressed her apology on her podcast while the other two YouTubers decided to apologize when interviewed by other YouTubers.

Table 2 Explicit Strategy of Apology

\begin{tabular}{|c|c|c|c|}
\hline Category & Sub & ategory & Excerpt from the videos \\
\hline $\begin{array}{l}\text { Explicit } \\
\text { Expression }\end{array}$ & A1 & A formative IFID & $\begin{array}{llll}\text { Pokoknya } \quad a k u & \text { mau } & \text { minta } & \text { maaf } \\
\text { (I just want to apologize) } & & & \end{array}$ \\
\hline Apology & A2 & $\begin{array}{l}\text { A Commissive with } \\
\text { "apology" as direct } \\
\text { object }\end{array}$ & $\begin{array}{l}\text { Dengan segala kerendahan hati saya memohon maaf kepada seluruh } \\
\text { orang yang merasa tersinggung, marah ataupun bersedih atas } \\
\text { konten yang upload. } \\
\text { (Modestly, I apologize to all those who feel offended, angry or sad } \\
\text { about the content that I uploaded) }\end{array}$ \\
\hline
\end{tabular}

The explicit strategy of apology can be found on IK and GA. They explicitly said "minta maaf" or "memohon maaf" (I beg apology, or I apologize) from what they have done, as seen in Table 2.

Table 3 Indirect Strategy of Apology

\begin{tabular}{|c|c|c|}
\hline Category & Sub-category & Excerpt from the videos \\
\hline \multirow{4}{*}{$\begin{array}{l}\text { Conventional } \\
\text { (indirect) } \\
\text { apology } \\
\text { formula }\end{array}$} & An expression of Regret & - \\
\hline & $\begin{array}{l}\text { A request for acceptance of } \\
\text { apology/forgiveness }\end{array}$ & $\begin{array}{l}\text { Sekali lagi atas hati yang tersakiti, saya memohon maaf. } \\
\text { (GA) } \\
\text { (Once again for the hurt. I apologize) }\end{array}$ \\
\hline & A statement of Desire & o \\
\hline & A Statement of Obligation & $\begin{array}{l}\text { Aku minta maaf kalau misalnya aku salah karena lagunya } \\
\text { mirip }(\mathrm{K}) \\
\text { (I am so sorry, if I am wrong, (because) the songs are quite } \\
\text { similar) }\end{array}$ \\
\hline
\end{tabular}

Moreover, GA and K showed conventional-indirect strategy in their apology. To be specific, they were in the category of request for acceptance and statement of obligation. It can be seen in Table 4.

Table 4 Non-conventional Indirect Strategy of Apology

\begin{tabular}{|c|c|c|c|}
\hline \multirow{2}{*}{$\begin{array}{l}\text { Broad } \\
\text { Category } \\
\text { Non- } \\
\text { conventional } \\
\text { Indirect } \\
\text { apology } \\
\text { strategy }\end{array}$} & \multicolumn{2}{|c|}{ Sub-category } & \multirow{2}{*}{$\begin{array}{l}\text { Excerpt from the Videos } \\
\text { Karena sebenernya aku pun pake masker dan aku tuh juga di tas aku } \\
\text { tuh aku slalu bawa tisu basah yang ada alkohol alkoholnya gitu aku } \\
\text { selalu bawa (IK) } \\
\text { (The truth was I used mask, and I always bring wet tissue containing } \\
\text { alcohol. I always bring it.) }\end{array}$} \\
\hline & $\mathrm{C} 1$ & $\begin{array}{l}\text { Explanation, account, } \\
\text { and excuse }\end{array}$ & \\
\hline & $\mathrm{C} 2$ & Accepting the blame & $\begin{array}{l}\text { Emang pure. bener kata kalian aku bodoh jadi di video itu aku bodoh } \\
\text { aku ngomong ga dipikirin dulu itu bener banget. (IK) } \\
\text { (Purely, I was stupid as you said, so in that video i was stupid. I didn't } \\
\text { weight my words. That was true.) }\end{array}$ \\
\hline & $\mathrm{C} 3$ & $\begin{array}{l}\text { Expressing } \\
\text { deficiency }\end{array}$ & - \\
\hline & $\mathrm{C} 4$ & $\begin{array}{l}\text { Recognizing of } \mathrm{H} \text { as } \\
\text { entitled to apology }\end{array}$ & $\begin{array}{l}\text { Aku sama sekali bukan untuk meremehkan tenaga medis, engga. (IK) } \\
\text { (I didn't mean to underestimate the medic) }\end{array}$ \\
\hline & $\mathrm{C} 5$ & $\begin{array}{l}\text { Expressing lack of } \\
\text { intent }\end{array}$ & $\begin{array}{l}\text { Aku ga pernah mikirin untuk menjiplak karya orang lain atau kaya } \\
\text { gimana gitu ga pernah ada niatan. }(\mathrm{K})\end{array}$ \\
\hline
\end{tabular}




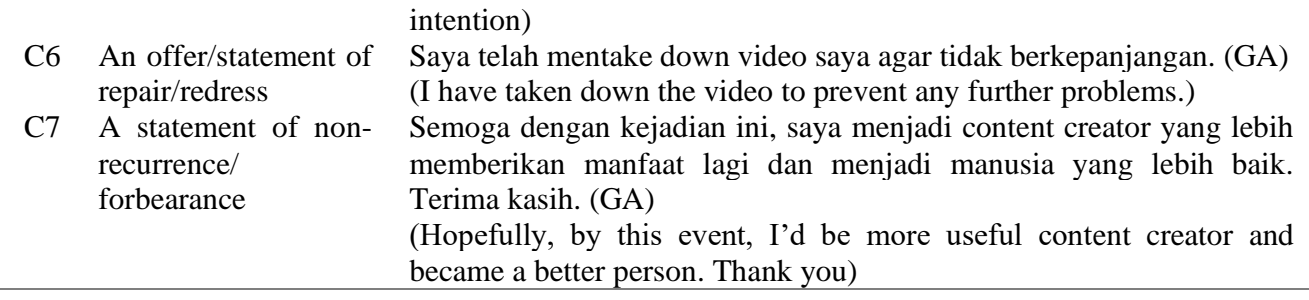

Concerning to non-conventional indirect strategy, this category was used by all public figures in expressing their apology, but they stated them in different ways. IK provides explanation and accepted the blame as well as she recognized of the hearer, the medic in this case, as entitled to her apology. Having no intention was one of $\mathrm{K}$ 's strategy in saying indirect apology. Giving repair, taking down the video from YouTuber in the case of $\mathrm{K}$, was her strategy to obtain the public's forgiveness. Furthermore, the last, GA stated her non-recurrence statement to express her apology in public.

\begin{tabular}{|c|c|c|c|c|c|}
\hline Sub-category & GA & IK & $\mathbf{U}$ & $\mathbf{K}$ & Total \\
\hline A1 A performative IFID & 1 & 1 & - & 1 & 3 \\
\hline A2 A commissive & 1 & 2 & 2 & & 5 \\
\hline $\begin{array}{ll}\text { B1 An expression of } \\
\text { regrets }\end{array}$ & - & - & - & - & - \\
\hline $\begin{array}{lll}\text { B2 } & \text { A request } & \text { for } \\
& \text { forgiveness }\end{array}$ & 1 & - & - & 1 & 2 \\
\hline B3 A statement of desire & - & - & - & - & - \\
\hline $\begin{array}{l}\text { B4 statement of } \\
\text { obligation }\end{array}$ & - & - & - & 3 & 3 \\
\hline $\begin{array}{l}\text { C1 Explanation, account, } \\
\text { and excuse }\end{array}$ & 4 & 1 & 3 & 5 & 13 \\
\hline C2 Accepting the blame & - & 3 & - & - & 3 \\
\hline C3 $\begin{array}{l}\text { Expressing } \\
\text { deficiency }\end{array}$ & - & - & - & - & - \\
\hline $\begin{array}{l}\text { C4 Recognizing of } \mathrm{H} \text { as } \\
\text { entitled to apology }\end{array}$ & - & 1 & - & 1 & 2 \\
\hline $\begin{array}{ll}\text { Expressing lack of } \\
\text { intent }\end{array}$ & 2 & 1 & - & 7 & 10 \\
\hline $\begin{array}{l}\text { C6 An offer/statement of } \\
\text { repair/redress }\end{array}$ & 1 & 3 & 1 & 1 & 6 \\
\hline $\begin{array}{l}\text { C7 statement of non- } \\
\text { recurrence/forbearance }\end{array}$ & 1 & - & - & - & 1 \\
\hline Total & & & & & 48 \\
\hline
\end{tabular}

In conclusion, the most frequent strategy of apology expressed by Indonesian public figures was non-conventional indirect strategy. Having no intention and giving explanation are ways of their asking for apology on the public. By saying these, they expect that public will understand the situations they encounter better and forgive them.

Social media facilitates public figures to seize popularity. Once the public on social media or internet citizen (netizen) found them violating norms and/or moral values in society, they use social media also to express their apology. Because of its 
wide coverage, social media becomes platform to express apologies to audiences, especially when the occurrence of offense originated from social media (Ulmer, Sellnow, \& Seeger, 2013).

\section{CONCLUSION}

This article has investigated apology strategies used by Indonesian public figures on YouTube. It is found that explanation, account, or excuse as the non-conventional indirect of an apology is the most frequent strategy, followed by expression of lack of intent and offer/statement of repair/redress, and public figures prefer to combine three or four strategies together in an apology.

We acknowledged that there are many limitations to the current study due to the small number of data set analyzed. Since more people are getting their news from online sources, the criteria that the apology is reported on YouTube or any media may have unfairly limited the number of apologies. YouTube was the only one social media platform to find out specific videos. Nowadays, there are other social media platforms that support online video sharing, including Twitter, Facebook, Twitch, and other social media platforms.

To build on this study, further studies may be conducted to examine public uptake/response of public apologies, and to analyze the representation of public apologies in the mainstream media and the effect of these representations on the perceived success of said apologies.

\section{REFERENCES}

Benoit, W. L. (1997). Image repair discourse and crisis communication. Public Relations Review, 23 (2), 177-186.

Brown, P., \& Levinson, S. (1987). Politeness: Some Universals in Language Use. Cambridge: Cambridge University Press.

Goffman, E. (1959). The presentation of the self in everyday life. New York: Anchor Books

Hargie, O., Stapleton, K., \& Tourish, D. (2010). Interpretations of CEO public apologies for the banking crisis: Attributions of blame and avoidance of responsibility. Organization, 17(6), 721-742.

http://doi.org/10.1177/1350508410367840

Holmes, J. (1990). Apologies in New Zealand English. Language in Society, 19(2), 155-199.

Johnson, S., \& Ensslin, A. (Eds.), (2007). Language in the media: Theory and practice. Language in the Media, Representations, Identities, Ideologie s. Continuum, London, pp. 3-24

Kadar, D. Z., Ning, P. Y., \& Ran, Y. P. (2018) Public ritual apology - A case study of Chinese. Discourse, Context \& Media, 26, 21-31. 
Kampf, Z. (2009). Public (non-) apologies: The discourse of minimizing responsibility. Journal of Pragmatics, 41 (11), 2257-2270.

Beaudin, L.M. (2018), I am sorry, we are sorry: A critical analysis of discursive strategies in contemporary public apologies.

Leech, G. N. (1983). Principles of Pragmatics. London: Longman

Murphy, J. (2014). Apologies in the discourse of politicians: A pragmatic approach. The University of Manchester (United Kingdom).

Ministry of Health of the Republic of Indonesia. (2020). Pedoman pencegahan dan pengendalian coronavirus disease (COVID-19) (Guidelines for Prevention and Control of Coronavirus Disease (COVID-19)). Jakarta: Ministry of Health of RI

Murphy, J. (2015). Revisiting the apology as a speech act: The case of parliamentary apologies. Journal of Language and Politics, 14(2), 175-204. http://doi.org/10.1075/jlp.14.2.01mur

Olshtain, E., \& Cohen, A. (1983). Apology: a speech-act set. In: Wolfson, Nessa, Judd, Elliot (Eds.), Sociolinguistics and Language Acquisition. Newbury House, Rowley, MA, pp. 18-35

Owen, M. (1983). Apologies and remedial interchanges. Mouton, Berlin.

Page, R. (2014). Saying 'sorry': Corporate apologies posted on Twitter. Journal of Pragmatics, 62, 30-45.

Sandlin, J. K., \& Gracyalny, M. L. (2018). Seshyaineking sincerity, finding forgiveness: YouTube apologies as image repair. Public Relations Review, 44, 393-406.

Searle, J. R. (1979). Expression and meaning: Studies in the theory of speech acts. Cambridge: Cambridge University Press.

Shahrokhi, M., \& Jan, J. M. (2012). The realization of apology strategies among persian males. Procedia - Social and Behavioral Sciences, 46, 692-700.

Trosborg, A. (1995). Interlanguage pragmatics: Request, complaints and apologies. Studies in Anthropological Linguistics. Mouton de Gruyter, Berlin.

Ulmer, R. R., Sellnow, T. L., \& Seeger, M. W. (2013). Effective crisis communication: Moving from crisis to opportunity. Thousand Oaks: Sage Publications.

Wouk, F. (2006). The language of apologizing in Lombok, Indonesia. Journal of Pragmatics, 38, 1457-1486. 